\title{
(Mis)Brugen af Sylvia Likens
}

\section{Fiktionaliseringer af et torturmord}

Den 26. oktober 1965 blev liget af den 16-årige Sylvia Marie Likens fundet på en beskidt madras i en ejendom på adressen 3850 East New York Street i Indianapolis, Indiana. Pigens krop var dækket af brændemærker og sår, og på hendes maveskind var der med en brændende varm nål ridset ordene "I AM A PROSTITUTE AND PROUD OF IT!" Siden august måned 1965 havde Sylvia og hendes lillesøster, Jenny, boet i huset hos den 37-årige Gertrude Baniszewski og hendes syv børn, mens deres forældre arbejdede i et omrejsende tivoli. Gertrude modtog 20 dollars om ugen for at passe Sylvia og Jenny. Det lykkedes først Gertrude at overbevise politiet om, at Sylvia var blevet mishandlet af en gruppe ukendte drenge - Gertrude havde tvunget Sylvia til at skrive et brev, som kunne bruges som bevis. Jenny fortalte dog politiet den makabre sandhed: Sylvia var død som følge af tre måneders tortur, orkestreret af Gertrude, hendes børn og adskillige børn og unge fra nabolaget. Herefter kom en retssag, som medierne og offentligheden fulgte nøje. Sagen blev af anklageren Leroy K. New kaldt "the most terrible crime ever committed in the state of Indiana" (Dean 2008, 1), og torturmordet på Sylvia Likens spøger stadig i amerikanske narrativer, hvor hun genoplives, (mis)bruges og myrdes igen og igen. Sylvia Likensfortællingerne skaber sammen et fælles indforstået sprog og en referenceramme bestående af elementer fra virkelighedens verden og interteksuelle henvisninger, som er unikke for netop denne sag, og som samtidig indgår i en større kontekst med andre døde piger og kvinder i amerikansk kulturproduktion. I processen skabes nye Sylvia-figurer, som distancerer sig fra virkelighedens Sylvia Likens, hvilket kan anses som endnu en voldshandling, da hun ingen kontrol har over, hvordan hendes historie fortælles, og hvad den bruges til.

Denne artikel vil vise, hvordan begrebet fiktionalisering kan bruges til at forklare, hvad der sker, når Sylvia Likens' historie laves til fiktion, og hvordan de forskellige fortællinger omhandlende mordet inddrager elementer fra virkelighedens verden og sammen skaber fiktionskendetegn, eller hvad Simona Zetterberg Gjerlevsen betegner som signposts i artiklen "Fictionality" (2016) i The living handbook 
of narratology. Disse fiktionskendetegn bygger bro mellem fiktion og virkelighed og gør læsere i stand til at identificere en tekst som værende en Sylvia Likens-tekst. Dermed læses Sylvia-figuren, skønt hun optræder under andre navne, som en kommentar på den virkelige Sylvia Likens, ofte med det resultat, at hun udskammes og bebrejdes for sin egen $\mathrm{d} \varnothing \mathrm{d}$.

\section{Kvindemord i true crime og fiktion}

Artiklens genstandsfelt begrænser sig til de forskellige bøger baseret på eller inspireret af sagen og kommenterer kun kort på andre slags tekster vedr. Sylvia Likens, såsom film, skuespil og installationskunst. Harvard-professoren Elaine Scarrys studie fra 1985, The Body in Pain: The Making and Unmaking of the World, bruges til at belyse, at victimblaming (bebrejdelse af offeret) og slutshaming (seksuel udskamning) er integreret i strukturen i fortællingerne om torturmordet på Sylvia Likens og er essentielle for den skabelses- og ødelæggelsesprocess, hun udsættes for i narrativerne. Figurtypen 'the beautiful dead girl's inddrages for at illustrere, hvordan Sylvia Likens’ historie indgår i en større kulturel kontekst. Denne figurtype har sine rødder i eurocentriske forestillinger om skønhed og heteronormative idéer om f.eks. køn, kyskhed og jomfrudom. Figuren anvendes i artiklen som et intersektionelt queer-feministisk værktøj for at påpege, hvorfor hvide piger og kvinder er overrepræsenteret i fortællinger om kvindemord, samt at denne trope bruges til at skabe cautionary tales (historier til skræk og advarsel), der fungerer som social kontrol.

Artiklen drager paralleller til en anden død (hvid) kvinde fra virkelighedens verden, Elizabeth Short, for at vise, at narrativerne om Sylvia Likens afspejler tendenser, der også ses i tekster omhandlende andre ofre for kvindemord, hvis historier fylder i den amerikanske bevidsthed. Artiklen refererer også til mordet på transmanden Brandon Teena i Falls City, Nebraska, i 1993 og viser, at fiktionaliseringen af mord kan fungere som en form for overgreb. Desuden inddrages figuren Laura Palmer fra David Lynch og Mark Frosts TV-serie Twin Peaks (1990-1991, 2017) som eksempel på dyrkelsen af døde piger og kvinder i amerikansk populærkultur. Skønt Laura Palmer er en fiktiv figur, kan (nogle af) hendes træk findes i virkelighedens verden i både historien om Marilyn Monroe samt mordet på Hazel Irene Drew i staten New York i 1908. Figuren Laura Palmer illustrerer, hvordan hvide piger og kvinders døde kroppe seksualiseres og gøres til æstetiske objekter, samt hvordan seksuel udskamning og bebrejdelse af ofre er integreret i narrativer omhandlende 'beautiful dead (white) girls', hvad enten de er fiktive eller holder sig til sagens fakta. Artiklen refererer også kort til Ingrid og Joachim Walls Bogen om Kim Wall: Når ordene slipper op (2018) som eksempel på et narrativ, som forsøger at modsætte sig fiktionaliseringen af et kvindemord.

Sylvia Likens' historie behandles både i f.eks. true crime-bøger og i romaner, der ofte præsenteres som fiktion baseret på virkelige hændelser. Konceptet fiktionalisering kan i forbindelse med en undersøgelse af Sylvia Likens-teksterne både bruges helt overordnet til at forklare, hvordan hendes historie bliver genstand for fiktive behandlinger, hvordan den virkelige Sylvia fordrejes og manipuleres med, og hvordan de forskellige romaner fungerer i samspil med hinanden, 
endda kommenterer hinanden, og sammen skaber en ny (eller flere nye) udgaver af Sylvia Likens, som læsere kan identificere via forskellige kendetegn, der kan spores tilbage til fakta vedr. mordet i 1965. De karakteriserer specifikt Sylvia Likens-narrativerne og er altså ikke universelle. Kendetegnene er nemme at identificere, hvis man kender til sagen, og underbygger den franske litteraturkritiker Gérard Genettes påstand om, at fiktionskendetegn kan forefindes i fiktion samt i fakta-tekster (Gjerlevsen 2016). Genettes definition af det paratekstuelle (1997) er nyttig i forbindelse med en undersøgelse af Sylvia Likens-teksterne, da forord, efterskrift og omslag ofte indeholder information til læseren om, hvilken kontekst vedkommende bør læse teksten ud fra. Parateksterne bliver en vigtig del af fiktionaliseringen af Sylvia i de forskellige tekster, da parateksterne ofte afslører forbindelsen mellem teksten og Sylvia Likens-sagen. F.eks. refererer de indirekte til sagen, og/eller skaber en distance mellem den virkelige sag og den fiktive fortælling, ved bl.a. at understrege, at teksten er inspireret af fakta, men også afviger fra dem. Gennem forord og efterskrifter får hver af Sylvia Likens-teksterne sin egen unikke ramme, som gerne indeholder en kritik af specifikke problematikker i det amerikanske samfund. Omslagene afslører et slægtskab mellem flere af romanerne. Fiktionskendetegnene i selve teksterne kobler fiktive fremstillinger af sagen til true crime-tekster, og sammen binder fiktionskendetegn og paratekster alle teksterne sammen, så de danner et 'Sylvia Likens Arkiv', en betegnelse lånt fra J. Halberstams kapitel om Brandon Teena, "The Brandon Archive", i In a Queer Time \& Place: Transgender Bodies, Subcultural Lives (2005). Læses Sylvia Likensteksterne, true crime-bøgerne såvel som romanerne i kronologisk rækkefølge, bliver det tydeligt, at forfattere bevidst skriver sig ind i denne samling af tekster, og at de er bekendte med hinandens bidrag til arkivet.

\section{Sylvia Likens Arkivet}

Virkelighedens Sylvia Likens overskygges af karakterer baseret på hende, og de fungerer alle som kommentarer på specifikke problematikker i det amerikanske samfund. Allerede i 1966, ét år efter forbrydelsen, udkom den første bog om mordet på Sylvia Likens: en true crime bog med titlen The Indiana Torture Slaying: Sylvia Likens' Ordeal and Death (genudgivet i 2008 som House of Evil: The Indiana Torture Slaying), skrevet af journalisten John Dean, som dækkede sagen for den lokale avis, Indianapolis Star. Siden er der med jævne mellemrum udkommet amerikanske bøger, som fiktionaliserer sagen - de læner sig op af fakta, men ændrer og tilføjer ofte begivenheder og navnene på de implicerede. Her kan nævnes den halvpornografiske roman The Martyr (1969) af beat-poeten David Meltzer, den stort set ukendte forfatter Mendal Johnsons eneste roman, Let's Go Play at the Adams' (1974), tydeligvis inspireret af William Goldings Lord of the Flies (1954) og Patte Wheats Pulitzernominerede By Sanction of the Victim fra 1976, som i forordet kategoriseres som "dramatized non-fiction in the form of a novel" (Wheat 1976, 5). Listen indbefatter også den feministiske teoretiker, kunstner og aktivist Kate Milletts studie fra 1979, The Basement: Meditations on a Human Sacrifice, som behandler historien fra et feministisk perspektiv og taler for og som Sylvia og Gertrude fra en jeg-fortællers 
synspunkt, og endelig den anerkendte gyserforfatter Jack Ketchums roman The Girl Next Door fra 1989, der bedst kan betegnes som torture porn, en gyser-subgenre associeret med film som f.eks. Hostel-serien (2005-2011) og Saw-serien (2004-2017).

Torture porn forbindes ofte med afsløringerne om amerikanernes brug af tortur efter terrorangrebet d. 11. september 2001, og dette forklarer måske, hvorfor hele to film om Sylvia Likens-sagen fik premiere i 2007: dramaet An American Crime og Jack Ketchum's The Girl Next Door, en gyserfilm baseret på Ketchums roman. Disse film kan læses som kritik af statsgodkendt tortur; i begge film finder torturen af Sylvia-karakteren kun sted, fordi en autoritet, i form af Gertrude-figuren, giver tilladelse til og opildner det. Senest udkommet er true crime bogen Sylvia: The Likens Trial (2014) af Forrest Bowman Jr., hvori forfatteren, som var forsvarsadvokat ved retssagen i 1965, fortæller detaljeret om selve retssagen, og digtsamlingen Bone China Girls: A Poetic Account of a Female Crime (2017) af underviseren og forfatteren Kori Frazier Morgan, som er bosat i Indianas nabo-delstat, Ohio. Der produceres altså stadig nye Sylvia Likens-narrativer.

Sylvia Likens Arkivet tæller også andre tekster og materialer, såsom skuespillet Down There (2010) af Randy Sharp, som er tilknyttet Axis Theatre i New York, true crime-bogen Torture Mom: A Chilling True Story of Confinement, Mutilation and Murder (2018) (med fokus på Gertrude) af den britiske forfatter Ryan Green, installationskunst af Kate Millett, dokumenter fra retssagen, avisartikler, breve, som Gertrude tvang Sylvia til at skrive, skriften på Sylvias hud, løgne og rygter, Gertrude spredte om Sylvia før hendes død, og forskellige steder og mindesmærker i Indianapolis knyttet til sagen. Som J. Halberstam, professor ved Columbia University, forklarer, har forskellige tekster baseret på et andet mord, nemlig drabet på transmanden Brandon Teena, tilsammen skabt et "Brandon Archive" (Halbertstam 2005, 22). Ligesom fiktionaliseringer producerer nye versioner af Sylvia Likens, har film såsom Boys Don’t Cry (1999) ifølge Halberstam bidraget til det evigt voksende arkiv og ligeledes været med til at skabe "a new 'Brandon"' (s. 23). I narrativerne gøres Brandon Teena til symbol, hans liv tilføres forskellige meninger, og han tvinges tilbage i rollen som "female victim" (s. 66). Fortællingerne om Brandon Teena fungerer altså som en slags overgreb, da hans identitet som transmand omgøres. Elizabeth Short, kendt som 'the Black Dahlia', blev myrdet i Los Angeles i 1947 og er endnu et eksempel på, hvordan den gentagne fiktionalisering af et mord fører til, at virkelighedens offer skubbes ud af sit eget narrativ. I Black Dahlia, Red Rose (2018) skriver forfatteren Piu Eatwell, at Shorts historie ofte er blevet fiktionaliseret for at gøre hendes grufulde mord til en moralsk lignelse - "a fable illustrating the dangers posed to women by early twentieth century "Hollywood"' (Eatwell 2018, 266) - hvis formål synes at være at opfordre piger og kvinder til at leve 'anstændige' liv. Som Eatwell forklarer, kan Shorts persona og historie frit manipuleres, så de passer til hvilken som helst agenda: "she will always be a cipher, a blank board upon which we can write our own story" (s. 267). Via forskellige fiktionaliseringer er Elizabeth Short nu blevet til mange Elizabeth'er: Hun er "Elizabeth, Betty, Bette, Beth, Gilda, the martyr, the angel, the whore, the icon. Elizabeth Short" (s. 267). Hun er på samme tid uhåndgribelig - blot "a hazy figure crossing a motel parking lot” (s. 267) - og plastisk, håndgribelig, nem at omforme og model- 
lere, fordi hendes liv og død stadig er præget af mysterier og spekulation. Hendes virkelige liv er blevet overskygget af myten 'the Black Dahlia'.

På samme måde er de forskellige Sylvia Likens-narrativer med til at skabe og genskabe Sylvia om og om igen; hun bliver til flere Sylvia'er. Da hun ofte optræder under et andet navn i fiktion, er hun derved også blevet til Rebecca (The Martyr), Barbara (Let's Go Play at the Adams'), Marjorie (By Sanction of the Victim) og Meg (The Girl Next Door). Læsere med kendskab til sagen kan dog identificere inspirationskilden via de forskellige tekstuelle markører eller signposts. Disse omfatter forskellige objekter, handlinger og/eller udtryk: det toastbrød, Sylvia blev tvunget til at spise, selvom hendes mund og hals var for tør til, at hun kunne synke det; cola-flasken, som hun blev tvunget til at voldtage sig selv med, mens hun stod afklædt foran Gertrude og børnene; brændemærkningen af hende med en ildrager og afklipningen eller afbrændingen af hendes hår; skriften på hendes mave (som i The Martyr bliver til "I AM THE WHORE OF BABYLON" (Meltzer 1969, 154), til "I FUCK FUCK ME" i Ketchums roman (Ketchum 2005, 283) og til blot "a vivid stripe across her belly" i Let's Go Play at the Adams' (Johnson 1974, 260)). Endelig kan man tilføje torturbødlernes motiver, herunder deres opfattelse af, at Sylvia - ved først at holde op med at reagere på torturen og dernæst $\mathrm{d} \varnothing$ - fratog dem retten til og fornøjelsen af at påføre hende smerte ("Barbara cheated them" (s. 260)).

En anden signpost er idéen om, at torturen af Sylvia var lige dele en leg ("Everybody's having fun with Sylvia" (Dean 2008, 44)), et eksperiment og en læringsproces, hvor Sylvia gennem straf skulle lære at opføre sig ordentligt. I narrativerne, såvel som i den virkelige mordsag, eskalerer torturen af Sylvia-figuren, når hun spærres inde i kælderen (i Wheats roman er det en garage), og denne placering af hende nedenunder signalerer, at enden på historien er nær. På samme måde som virkelighedens torturbødler og overgrebspersonerne i romanerne "morede sig" med Sylvia, leger forfattere med hendes historie og med hendes krop, når de eksperimenterer og finder på nye former for tortur at udsætte hende for, såsom fuldbyrdet voldtægt (i flere af narrativerne) og en klitoridotomi (i The Girl Next Door). Sylvia Likens (mis)bruges altså stadigvæk, og i fiktionaliseringerne af hendes historie genskaber og viderefører forfattere den virkelige forbrydelses dehumanisering.

Forfattere låner ofte elementer fra tidligere Sylvia Likens-historier og derved skabes der en intertekstuel sammenhæng mellem narrativerne og nærmest en tradition for, hvordan en Sylvia Likens-fortælling sættes sammen. F.eks. minder dyremishandleren Woofer i Ketchums roman fra 1989 meget om karakteren Gopher i Meltzers roman fra 1969, og i The Basement refererer Millett direkte til Deans bog og skriver, "I owe this author my sincere thanks" (Millett 1991, 31). Paratekster i form af omslagene på flere af bøgerne tydeliggør også slægtskabet; dukker, som forestiller hvide småpiger med uglet hår og slitage eller afrevne lemmer, figurerer på forsiden af Johnsons (1976-udgaven), Wheats og Frazier Morgans bøger. På forsiderne af Meltzers roman, 1974-udgaven af Johnsons roman og 2008-udgaven af Ketchums roman (de tre narrativer, der synes at erotisere Sylvias lidende krop mest) er personerne afbildet i sårbare situationer; de er nøgne eller halvt afklædte, lidende og enten bundet eller med bind for øjnene. 


\section{Sylvia sættes i kontekst}

Flere af Sylvia Likens-narrativerne indeholder paratekster i form af forord og/eller efterskrifter, hvori sagen (som ofte ikke refereres til direkte) sættes i sammenhæng med forskellige problematikker. Teksterne kan derved læses som kritikker af samtiden og samfundet og evt. anmodninger om handling. Narrativet rammesættes, og læseren opfordres til at tolke historien ud fra en specifik kontekst. I den første bog om Sylvia Likens-sagen - Deans House of Evil - drager anklageren Leroy K. New i forordet paralleller mellem torturen af pigen og samtiden, 1960'erne, som var præget af politisk turbulens og bevægelser, der kæmpede for minoriteters rettigheder. New ser Gertrude og børnenes handlinger som bevis på samfundets "massive moral breakdown" (Dean 2008, x), som får folk til at bruge metoder såsom civil ulydighed. Torturen af Sylvia afspejler altså, ifølge New, farlige tendenser, som vil sprede sig, hvis ikke ordensmagten forhindrer det. Fokus flyttes fra Sylvia Likens selv og over på, hvad sagen tilsyneladende afslører om det amerikanske samfund generelt.

Meltzers roman fra 1969, The Martyr, bliver i et postscriptum af science fictionforfatteren Frank M. Robinson fremstillet som et modsvar til seksuel puritanisme. Robinson skriver, at institutioner som f.eks. kirken, samfundet og familien har reduceret sex til blot at handle om funktion og ikke om glæde (Meltzer 1969, 175). Ifølge Robinson skildrer Meltzers "nightmare novel" (s. 175), hvordan "sex maniacs" (s. 171) begår overgreb, fordi samfundet udhungrer dem seksuelt ved at tvinge dem til at associere lyst med skam (s. 175). Inde i selve historien projicerer den jødiske Meltzer sig selv over på Sylvia-karakteren, da han gør hende til datter af en jødisk far og bruger hende til at kommentere på jødeforfølgelsen. Rebecca beskrives som mørklødet og mystisk og bliver racialiseret som værende andet end hvid. Hun er dog lys nok til, at de hvide drenge stadig læser hende som attraktiv, bedømt ud fra eurocentriske skønhedsidealer; hun har både et "dark mysterious face" (s. 45) og "white flesh" (s. 66). Rebeccas jødiske aner gør hende anderledes og dragende i drengenes øjne, men samtidig bliver dette brugt til at nedgøre hende. Romanens Gertrude-figur, Lorna, giver f.eks. udtryk for antisemitisme, når hun refererer til Rebeccas far som "that Jew" (s. 87) og siger til sin søster, Zelda (Rebeccas mor), at hendes mand har forurenet hendes blod og hendes livmoder, og altså også hendes børn (s. 87). Ifølge Lornas logik er Rebeccas jødiske afstamning bevis på, at hun er en "whore" (s. 87): hun er af natur beskidt og skal derfor udryddes. I Meltzers roman kan Lorna og børnene læses som stand-ins for nazisterne og Rebecca som symbol på de jøder, der mistede deres liv under Holocaust. Meltzers egen baggrund bliver derved en integreret del af det kvindehad, Sylvia-figuren udsættes for.

Wheats By Sanction of the Victim fra 1976 bruges til at gøre opmærksom på Parents Anonymous, en støtteforening for forældre, der forsøger at bryde med et voldeligt mønster, hvor vold avler vold. I forordet og efterskriftet forklarer stifterne af foreningen, Leonard L. Lieber og Jolly K., hvor realistisk romanen skildrer børnemishandling. Der refereres igen ikke direkte til Sylvia Likens-sagen, men i forordet skriver Lieber, at begivenhederne i bogen er "documented and a matter of court records" (Wheat 1976, 5). I både forordet af Lieber og efterskriftet af Jolly K. bruges sagen til at belyse børnemishandling som et generelt problem, der kan lokaliseres 
i alle samfundslag. Lieber slutter sit forord af med at appellere til voldelige forældre om at søge hjælp. I efterskriftet fortæller Jolly K. desuden, hvordan hun, som offer og voldsperson, identificerer sig med både Sylvia-karakteren, Marjorie, og Gertrude-karakteren, Florrie, og hun slutter af med en bøn til læseren om at bede om hjælp, før det er for sent: "If you don't, the 'Marjorie' who you know today may well become tomorrow's 'Florrie"' (s. 208). For Jolly handler Wheats historie (og Sylvias) først og fremmest om, hvor nemt et offer selv kan begå overgreb. Fokus her synes altså ikke at være at fortælle Sylvias Likens' historie, men at anvende den til at rette fokus mod en specifik forening, dens medlemmer og fremtidige medlemmer.

I The Basement fra 1979 bruger Millett Sylvia Likens' historie til at vise, hvordan misogyni kommer til udtryk via mord på kvinder. Også Milletts Sylvia bliver en symbolsk karakter, hvis historie handler om generel seksuel udskamning af piger og kvinder (Millett 1991, 3) og om, hvordan de lærer at frygte at blive myrdet: "I was Sylvia Likens. She was me.... She was the terror at the back of the cave, she was what 'happens' to girls. Or can. Or might" (s. 14). Ved at fortælle Sylvias historie ved at "meditere" over sagen og fiktionalisere begivenhederne - ville Millett redde Sylvia, være hendes "champion" (s. 4). I introduktionen til udgaven fra 1991 skriver Millett, at hun håbede, at bogen ville forandre og endda redde kvinders liv: "I had once imagined I could prevent other deaths - those of the next victims" (s. 4). Millett $\varnothing$ nskede, at The Basement skulle være et banebrydende feministisk studie, men ifølge Millett var de amerikanske feminister i slutningen af 1970'erne ikke klar til at se kvinder som medvirkende til deres egen undertrykkelse; deres ideologi kunne ikke rumme Gertrude og hendes internaliserede kvindehad. Selvom bogen nævner Sylvia og de andre implicerede ved navn, handler denne fortælling dog også først og fremmest om Milletts feministiske udgangspunkt, og hvordan sagen relaterer til hendes egen oplevelse af at vokse op som kvinde.

Sylvia Likens-narrativerne handler altså ikke så meget om Sylvia selv, men mere om forfatterens egen læsning af sagen samt vedkommendes projicering af sig selv på hendes historie. Sylvia er nem at skrive om og fiktionalisere, fordi så lidt information om hendes liv er offentligt tilgængelig - hun er i forvejen et blankt lærred og hendes liv (og død) kan nemt digtes frit, uden at kunstneren kan klandres for direkte at fabrikere usandheder om hende - specielt ikke, når hun samtidig får et nyt navn. Hendes narrativ blev endda overtaget af Gertrude, før Sylvia døde, da Gertrude dikterede usandheder, som Sylvia skrev ned under tvang. Fiktionalisering spillede altså en rolle i den originale tortur af Sylvia, og det store vidensgab i sagen er netop Sylvias egen oplevelse og hendes egen stemme, som Gertrude undertrykte via forskellige former for tortur, der til sidst medførte døden. Sylvia blev tvunget til, først via ord, at begå overgreb mod sig selv i breve, der fremstillede hende som en fristerinde, der var skyld i sin egen død. Denne handling - denne appropriation gentages i fiktionaliseringerne af Sylvias tortur og død.

\section{Smukke døde (hvide) piger}

Sylvia Likens og Elizabeth Short er begge amerikanske ikoner, som udelukkende er kendte på grund af deres død. Konceptet 'den smukke døde pige' ('the beautiful 
dead girl') kan bruges til at forklare, hvorfor deres død fik så megen omtale, og hvorfor de stadig er en del af den amerikanske bevidsthed. Eatwell understreger, hvor vigtige Elizabeth Shorts fysiske karakteristika er for hendes evige popularitet: "all that matters for the purposes of her legend living on is that she was young and beautiful" (Eatwell 2018, 267). Hendes ungdom og skønhed er altså nok til, at hun automatisk beslægtes med andre smukke unge døde kvinder, der pryder omslagene på true crime-bøger og dominerer overskrifterne i aviser. Som kritiker og professor Elisabeth Bronfen påpeger i sit studie fra 1992, Over Her Dead Body: Death, Femininity and the Aesthetic, er vi i Vesten så vant til at se døde kvinder afbildet som smukke, æstetiske objekter, at denne form for repræsentation er blevet normaliseret: "representations of feminine death work on the principle of being so excessively obvious that they escape observation. Because they are so familiar, so evident, we are culturally blind to the ubiquity of representations of feminine death" (Bronfen 1992, 3). Tropen 'the beautiful dead girl' er altså på samme tid allestedsnærværende og usynlig.

Dyrkelsen af det smukke kvinde-lig sættes ofte i forbindelse med Edgar Allan Poes essay fra 1846, "The Philosophy of Composition", som han skrev efter kriminovellen "The Mystery of Marie Rogêt" fra 1842, der var inspireret af Mary Cecilia Rogers' (kendt som 'the Beautiful Cigar Girl') mystiske død i New York i 1841. I sit essay ophøjer Poe den smukke kvindes død: "the death, then, of a beautiful woman is, unquestionably, the most poetical topic in the world" (Poe 1993, 109). Poes syn på det smukke kvinde-lig som æstetisk objekt har sat sine spor i f.eks. de nærmest formulariske TV-serier, hvor en smuk piges død sparker narrativet i gang. I amerikansk popkultur står Twin Peaks' Laura Palmer som indbegrebet af 'the beatiful dead girl', hvis død er uundværlig for plottets fremskriden, og hvis skønhed og formodede 'godhed' vækker publikums empati, og gør dem interesserede i, at sagen bliver opklaret. Som den amerikanske forfatter Alice Bolin skriver i essaysamlingen Dead Girls: Essays on Surviving an American Obsession (2018), er Twin Peaks det første eksempel på den genre, hun refererer til som "the Dead Girl Show" (Bolin 2018, 1). Det er en særlig type serie, hvor efterforskere forsøger at løse mysteriet om mordet på en smuk pige. Narrativet omhandler dog sjældent offeret selv; i stedet bliver mordet på hende brugt til at sætte fokus på eventuelle problemer og hemmeligheder i hendes hjemby. Eller også fungerer hendes død primært som motivation for den mandlige helts hævntogt. Ofte udskammes offeret på grund af hendes seksuelle hemmeligheder, og hun bliver syndebuk for det lille samfund. Der synes altså at være samspil mellem, hvordan virkelighedens døde piger og kvinder og (halvt) fiktive ditto bliver brugt i narrativer.

I fortællingerne om Sylvia Likens behandles mordet på hende som symptomatisk på forskellige onder i samfundet, og Sylvia-figuren tager ofte del i eller tvinges til tabubelagte seksuelle aktiviteter, som forklarer torturbødlernes motiver og lægger en del af skylden over på offeret. F.eks. har hun i The Martyr både et incestuøst forhold til sin bror, Jeremy, og er blevet misbrugt af sin onkel (Lornas mand), og i By Sanction of the Victim manipulerer Marjories stedfar hende til at tro, at hans grænseoverskridende adfærd er udtryk for kærlighed. I begge bøger har Gertrude-karakteren mistanke om, at pigen har været eller er seksuelt aktiv, og via tortur forsøger 
hun at få Sylvia-figuren til at indrømme det. Disse opdigtede elementer bygger videre på, at virkelighedens Sylvia indrømmede over for Gertrude og hendes døtre, at hun engang havde ligget under dynen sammen med sin kæreste. Ifølge Deans bog afslørede Sylvia ikke, at hun havde haft samleje med kæresten, men alligevel førte det til, at Gertrude beskyldte Sylvia for at være gravid og sparkede hende i skridtet. Sylvias indrømmelse synes at være blevet brugt af Gertrude som en undskyldning for eskaleringen af volden og afstraffelsen af pigen pga. 'syndig' adfærd.

Selvom en smuk ung piges død spiller en central rolle i et narrativ, er hun ofte allerede $\mathrm{d} \varnothing \mathrm{d}$, skrevet ud af narrativet, når historien starter, som den amerikanske forfatter og kritiker Maggie Nelson påpeger i The Art of Cruelty: A Reckoning (2011): "the female is always already dead: that is how the plot begins. Indeed, there can be no plot without her death - without it, what would there be to find out, explain, or avenge?” (Nelson 2011, 165-166). Smukke døde piger og kvinder fungerer derved ofte blot som rekvisitter i disse historier. På samme måde er Sylvia Likens’ død i 1965 en forudsætning for, at fortællingerne om hende eksisterer. Kender man til sagens fakta, er Sylvia, selv om hun genoplives af forfatteren, før narrativet starter, altid allerede død.

For at forstå hvorfor netop de ovennævnte døde kvinder fylder så meget i amerikansk og vestlig kultur, er det nødvendigt at udvide konceptet 'the beautiful dead girl' ved hjælp af et intersektionelt og queer-feministisk perspektiv og undersøge, hvilke piger og kvinder inkluderes i kategorien, og hvilke der sorteres fra. Under denne 'sortering' spiller faktorer som f.eks. eurocentriske skønhedsidealer (hvidhed som tegn på skønhed), race, klasse og heteronormative idéer vedrørende køn, seksuel aktivitet og uskyld/jomfrudom ind. Det såkaldt 'perfekte offer' er hvid, smuk, ung, tilhører middel- eller overklassen, er heteroseksuel og ciskønnet, og har enten haft sex med så få mænd, at hun stadig kan kategoriseres som ærbar, eller er jomfru (og jomfrudom skønnes ud fra, om hun har haft hetero-sex i form af penis-i-vagina-penetration). Som Nelson påpeger i The Red Parts: Autobiography of a Trial (2007), er der i true crime-genren en overvægt af historier om "the bizarre, violent deaths of young, good-looking, middle- to upper-class white girls" (Nelson 2007, 68). Hun refererer til dette fænomen som "the dead-white-girl-of the-weekclub" (s. 174). Omvendt får f.eks. de mange mord på queer kvinder, transkvinder, kvindelige sexarbejdere og sorte kvinder meget lidt opmærksomhed fra medierne og i populærkulturelle tekster.

For at passe ind i kategorien 'beautiful dead girl' behøver et offer ikke at opfylde alle de ovennævnte kriterier; Sylvia Likens var fattig, men de sensationelle aspekter ved sagen (tortur begået af en voksen kvinde og hendes børn) var med til at skabe opmærksomhed omkring hendes død. Retsmedicinerens konklusion om, at Sylvia var jomfru, da hun døde (han mente ikke, hun havde haft penis-i-vagina-sex eller var blevet voldtaget) samt faderens forsikring i retten om, at hans datter var en 'god pige' fungerer som formildende omstændigheder. I narrativer om 'beautiful dead girls' er der dog et interessant sam- og modspil mellem koncepterne hvidhed, seksuel 'renhed' og udskamning. Twin Peaks illustrerer dette via kontrasten mellem de fotografier, der vises af Laura. Billedet af Laura fra skoleballet, hvor hun smiler og håret prydes med en tiara, refererer til den Laura, familie, venner og byen sørger 
over ('den gode pige'), mens billedet af hende, hvor hun optræder anonymt i en kontaktannonce i pornobladet Flesh World, repræsenterer den Laura, hvis hemmeligheder afsløres, efterhånden som narrativet foldes ud. Da det viser sig, at Laura deltog i orgier, arbejdede på bordel og var afhængig af kokain, præsenteres hun som værende medskyldig i sin egen død. Laura udskammes for sin seksualitet, mens skylden fjernes fra hendes far, som kun misbrugte og myrdede hende, fordi han var besat af dæmonen BOB. Den virkelige skurk i Twin Peaks er Laura, hvis død bragte alle byens beskidte hemmeligheder frem i lyset. Denne kombination af victimblaming og slutshaming synes at være en fastømret del af strukturen i 'beautiful dead girl'-narrativer.

Netop denne fremstilling af et kvindeligt mordoffer som meddelagtig i egen død synes ofte at være til stede, når myrdede kvinders stemmer og historier approprieres af andre. I Bogen om Kim Wall: Når ordene slipper op (2018) giver Ingrid Wall, Kim Walls mor, gentagne gange udtryk for, at bogen delvist er et forsøg på at få kontrol over hendes datters narrativ, inden hendes historie fordrejes og fiktionaliseres af andre: "Vi siger gang på gang nej til at lade os interviewe, selvom alle vil fortælle den virkelige historie om, hvordan Kim var. Det er kun os, som kan fortælle den historie, og det vil vi gøre på vores måde, når tiden er inde" (Wall 2018, 245). Kim Walls familie har ressourcerne til at forhindre, at hendes bedrifter som journalist og som menneske overskygges af makabre detaljer vedrørende torturmordet på hende. Deres hensigt er at udfordre de formanende narrativer, der fokuserer på, hvordan Kim Wall kunne have ageret anderledes og aktivt gjort noget for at undgå at blive dræbt. Der findes ingen bog om Sylvia Likens skrevet af dem, der kendte hende, hvilket på sin vis beskytter hendes privatliv, men også åbner op for, at folk frit kan opdigte historier om hendes liv og tilpasse dem en ny agenda.

\section{Afstraffelsen af den rebelske pigekrop}

For at svare på, hvorfor netop Sylvia blev mishandlet, portrætterer narrativerne hende ofte som en, der går imod det normative, altså som en queer figur. Sylvias anderledeshed bruges til at lægge skylden over på offeret i stedet for gerningspersonerne; Sylvia bliver ikke blot tortureret, fordi hendes torturbødler er styret af kvindehad, men fordi der er noget ved hende, specifikt, som gør folk vrede. I The Basement forklarer Millett, at hun skrev Sylvia som "a tomboy, an androgyne, a mind, a cutup, a rebel, one who drew fire” (Millett 1991, 6). I Ketchums roman imponerer Meg nabodrengen David, fordi hun ikke er som andre piger (Ketchum 2005, 11): Meg bevæger sig med en selvtillid og styrke, som David ellers kun observerer hos andre drenge. Hun er både "[t]he prettiest girl I'd ever seen" (s. 8) og har "this strong hard body and easy grace about her" (s. 11). Hvor David ser Meg som en slags heltinde (s. 27), læser Gertrude-karakteren Ruth hende som en "slut" (s. 99), udelukkende fordi Meg er sværere at kue end de andre børn. Der er noget voksent over Megs adfærd, som for eksempel da hun udfordrer Ruths autoritet og ikke er "powerless" (s. 129), som børn normalt er. Det er denne rebelskhed, denne udfordring af autoritet og heteronormativitet, som både Millett og Ketchum fremstiller som en af grundene til, at Sylvia-karaktererne bliver mishandlet. 
I Sylvia Likens-narrativerne fremstilles hun ofte som noget særligt, og som en kontrast til Gertrude-karakteren, hvis krop er blevet nedbrudt af fattigdom, sygdom, depression og graviditeter. Disse narrativer minder meget om klassiske eventyr, såsom Askepot, hvor pigens skønhed og ungdom - "She was slender and pretty and in the bloom of her life" (Dean 2008, 21) - fremprovokerer jalousi og had i den ældre kvinde, som ofte er en slags heksefigur (hos Meltzer omtales Lorna som "Old witch Lorna" (Meltzer 1969, 23)). I The Martyr er Rebecca drømmepigen, som drengene bliver besat af; hendes skønhed fører f.eks. til, at karakteren Gopher oplever sin seksuelle opvågnen. Han føler en "strange new activity in his groin" (s. 24), når han tænker på hende, og karakteren Marco begynder at fantasere om Rebecca, når han er sammen med sin kæreste, Nina: "Nina is replaced by Rebecca. He sees Rebecca's dark mysterious face" (s. 45). Gertrude-karakteren, Lorna, fremstilles derimod som aldrende, tynd og benet (s. 39). Den skelet-agtige Lorna forårsager død og er samtidig også selv mærket som døende på grund af sine egne fysiske og psykiske smerter. Hendes åreknuder, strækmærker og bryster, der er "tiny and shriveled" (s. 40), bliver brugt til at fremstille hende som et stereotypt billede af en kvindekrop, der dømmes til at være uattraktiv ifølge vestlige skønhedsidealer. Netop Lornas mistede ungdom og skønhed og hendes opfattelse af, at drenge og mænd ikke længere finder hende attråværdig og foretrækker Rebecca, bruges til at forklare, hvorfor hun udsætter pigen for tortur. Rebeccas køn - hendes spirende kvindelighed - er afgørende for, hvorfor hun bliver mishandlet og myrdet og for, hvilke former for tortur, såsom voldtægt, hun udsættes for, og volden kan læses som udtryk for den misogyni, Lorna har internaliseret.

Udover at se sin egen krops forfald kontrasteret i Rebeccas unge krop læser Lorna teenagerens krop som korrumperet af synd - "I can smell the musk of violent sin from Rebecca" (s. 26) - og dette element går igen i flere af Sylvia Likens-narrativerne. Især skriften på hendes krop markerer Sylvia-karakteren som syndefuld, og via denne markering og i de forskellige budskaber, der skrives på hende i narrativerne, drages der paralleller til andre kendte syndige kvindefigurer som f.eks. Hester Prynne i Nathaniel Hawthornes klassiker The Scarlet Letter (1850) og den bibelske figur Den babylonske skøge ("I AM THE WHORE OF BABYLON" (s. 154)). Gertrude-karakteren opfatter sex som synd - en synd, der har resulteret i, at hun er enlig forsørger og lever i fattigdom. Hun overbeviser sig selv om, at hun gør Sylviakarakteren en tjeneste ved gennem tortur at forandre hendes krop fra at være attråværdig til at være frastødende. Som Ruth konkluderer i The Girl Next Door: "When you learn so much, it becomes your obligation to teach the lesson, bitter as it may be" (Ketchum 2005, 38). Flere af narrativerne indeholder ekkoer af virkelighedens Gertrudes kommentar til Sylvia - f.eks. hører vi hende sige de autentiske ord: "You can't get married now" (Dean 2008, 72) - efter det udskammende narrativ er blevet brændt ind i Sylvias hud. Som Ketchum skriver, har Ruth permanent ændret Meg, blandt andet ved at brænde hendes klitoris af i et fors $\emptyset \mathrm{g}$ på at fjerne hendes seksuelle drifter. I Ruths øjne er denne forandring positiv ("A woman's better off loathsome in this world" (Ketchum 2005, 283)), netop fordi pigens nye, afseksualiserede og derfor forbedrede krop redder hende fra ægteskab, moderskab og fattigdom. Meg er nu "perfect" (s. 287). 
Elaine Scarrys teori om de forskellige processer, der finder sted, når et menneske bliver udsat for tortur, som beskrevet i The Body in Pain, belyser ødelæggelsen af Sylvia-karakterens krop og sind, der finder sted i narrativerne. Gradvist forvandles den smukke unge pige til "a filthy creature" (Meltzer 1969, 121), der tvinges til at spise og sove og besørge det samme sted. Scarry forklarer, at tortur har en meget snæver og ensartet struktur (Scarry 1985, 19): først påføres offeret smerte, som bliver mere intens, så gøres smerten synlig for andre (så den ikke længere er afgrænset til at være inden i offerets krop), og til sidst benægtes smerten og præsenteres i stedet som et bevis på bødlens (og det regime vedkommende agerer på vegne af) magt. I alle narrativerne udsættes Sylvia-karakteren for tortur, der gradvist bliver mere og mere voldsom. Kroppen tilføres konstant nye sår og skader, som vidner om den smerte, Sylvia-karakteren føler. Både i virkeligheden og i fiktionaliseringerne af torturmordet anerkendte Gertrude ikke, at Sylvia var i stand til at føle smerte. Som Dean forklarer, nægtede Gertrude til det sidste at indse, at Sylvia var døende. Umiddelbart før Sylvia udåndede kaldte Gertrude hende for en "Faker!" (Dean 2008, 82) og slog hende med en bog. På samme måde kalder Florrie i By Sanction of the Victim Marjorie en faker og beordrer hende til at "[s]top your moaning" (s. 70), som om Marjorie kan kontrollere, hvordan hun reagerer på smerte, såsom da Florrie sparker hende i skridtet (Wheat 1976, 69-70). Denne reduktion af offeret til ikkemenneskeligt væsen uden følelser er en essentiel del af tortur og vidner om processens dehumanisering.

Som Scarry forklarer, går dødsprocessen i gang, så snart en person bliver klar over, at døden er nært forestående: "Whenever death can be designated as 'soon' the dying has already begun" (Scarry 1985, 31). Bevidstheden om, at døden snart vil indtræffe, får personen til at læse sin krop som døende (s. 31). I Sylvia Likens-narrativerne er historiens struktur også fastsat fra starten: allerede når Sylvia-karakteren ankommer til Gertrude-karakterens hus, starter nedbrydningsprocessen, og det er uundgåeligt, at pigen skridt for skridt vil nærme sig narrativets og livets ende. Selv hvis Sylvia-karakteren skulle overleve - i Wheats bog er det f.eks. uklart, om hun overlever - er karakteren alligevel mærket som død/døende på grund af Sylvia Likens’ død i 1965. I fiktionaliseringer kan hun dog reanimeres igen og igen.

\section{Når smerten udsletter sproget}

Scarry forklarer også, hvad der sker med offerets sprog under tortur: torturbødlen påfører offeret fysisk smerte og udsætter vedkommende for forhør, og disse handlinger er med til at tilintetgøre både offerets krop og sprog. Torturbødlen igangsætter en slags optrævling af sprogtilegnelsesprocessen, hvor offerets sprog skridt for skridt tvinges til at bevæge sig baglæns mod den førsproglige fase (s. 20). Dette kommer til udtryk i offerets brug af førsproglige lyde - "the sounds anterior to language" (s. 49) - som f.eks. de skrig, offeret kommer med, når smerten bliver uudholdelig. Ifølge Scarry handler selve forhøret ikke så meget om, hvilken information torturbødlen kan få ud af offeret, men om selve nedbrydningen af personens menneskelighed. I Sylvia Likens-narrativerne forsøger Gertrude-karakteren ofte at få 
Sylvia-karakteren til at indrømme, at hun er promiskuøs. Hvis Sylvia-karakteren ikke selv fortæller om eventuelle seksuelle oplevelser, opdigter Gertrude-karakteren historier, der bruges som motiv for afstraffelsen af pigen. Formålet er altså ikke at få pigen til at tilstå, men at udskamme hende og få det til at virke som om, hun selv er skyld i den tortur, hun udsættes for. Selve indholdet af det, offeret siger, er ikke vigtigt - det vigtige er at få hende frem til det stadie, hvor smerten fylder alt, og hvor hun kun kan skrige. Milletts adaption ender med, at Sylvia-karakteren mister stemmen helt og kun kan høre et skrig inde i hovedet, lige før hun dør: "it's like all the insides of me screams [sic]. This kinda scream inside your head" (Millett 1991, 341). Når Sylvia får stjålet sin stemme, og hendes historie fiktionaliseres, manipuleres og tilpasses en specifik agenda, efterligner denne proces torturen og forlænger den i stedet for at omstøde den.

Scarry pointerer, at når der sættes ord på oplevelsen af smerte og oplevelsen af at have befundet sig på det førsproglige stadie, enten af den, der har overlevet smerten, eller af dem, der taler/skriver på offerets vegne (f.eks. hvis torturofferet er død), er det som om, at de medvirker i 'fødslen' af sprog (Scarry 1985, 6). Gennem smerte nedbrydes sprog altså og reduceres til førsproglige lyde, og når smerten bagefter beskrives med ord, genopstår eller genfødes sproget. I Sylvia Likens-fortællingerne genskabes både hun og hendes sprog altså, for blot at blive nedbrudt igen, både af torturbødlerne og af forfatterne. Hver gang en ny Sylvia træder over dørtærsklen til Gertrudes hjem, starter en ny skabelsesproces, som samtidig er en destruktion af Sylvias krop, sind og sprog: hendes unmaking er en uundgåelig del af hendes making og en integreret del af strukturen i narrativerne i Sylvia Likens Arkivet, ligesom de forskellige (inter)tekstuelle markører. Torturbødlernes inskription på hendes krop, det originale udskammende narrativ, gentages i forskellige fiktionaliseringer, hvor det kort opsummerer og afspejler den større fortælling om både Sylvia Likens og om andre ikoniske døde piger og kvinder i amerikansk kultur. Dette narrativ - "I AM A PROSTITUTE AND PROUD OF IT!" og den victimblaming og slutshaming, det indeholder, bliver, i alle dets variationer, til sidst den altoverskyggende historie om Sylvia Likens. Via fiktionaliseringerne af historien om hendes død smelter virkelighedens Sylvia Likens sammen med Rebecca, Barbara, Marjorie og Meg, og hendes egen stemme fra virkelighedens verden drukner i deres skrig.

\section{Noter}

I Som så mange andre figurtyper kan dennes rødder spores tilbage til klassiske eventyr, som f.eks. Snehvide. I Dead Girls: Essays on Surviving an American Obsession (2018) påpeger Alice Bolin, at amerikanske TV-serier siden Twin Peaks (1990-1991) har afbildet den ultimative "dream girl" som en død pige (Bolin 2018, 10).

\section{Litteratur}

Bolin, Alice (2018): Dead Girls: Essays on Surviving an American Obsession, New York: Harper Collins. 
Bowman, Forrest Jr. (2014): Sylvia: The Likens Trial, Indianapolis: Legis Fabulae Publishing. Bronfen, Elisabeth (1992): Over Her Dead Body: Death, Femininity and the Aesthetic, Manchester: Manchester University Press.

Dean, John (2008): House of Evil: The Indiana Torture Slaying, New York: St. Martin's Press. Eatwell, Piu (2018): Black Dahlia, Red Rose, London: Coronet.

Genette, Gerard (1997): Paratexts: Thresholds of Interpretation, Cambridge: Cambridge University Press.

Gjerlevsen, Simona Zetterberg (2016), "Fictionality", i Peter Hühn et al. (red.): The living handbook of narratology, Hamburg: Hamburg University Press, https://www.lhn.uni-hamburg.de/ node/138.html

Halberstam, Judith (2005): In a Queer Time and Place: Transgender Bodies, Subcultural Lives, New York: New York University Press.

Johnson, Mendal (1974): Let's Go Play at the Adams', London: Granada Publishing Limited.

Lynch, David og Mark Frost (1990-1991): Twin Peaks, ABC.

Ketchum, Jack (2005): The Girl Next Door, New York: Leisure Books.

Meltzer, David (1969): The Martyr, North Hollywood: Essex House.

Millett, Kate (1991): The Basement: Meditations on a Human Sacrifice, New York: Touchstone.

Millett, Kate (1994): The Politics of Cruelty. An Essay on the Literature of Political Imprisonment, London: Viking.

Morgan, Kori Frazier (2017): Bone China Girls: A Poetic Account of a Female Crime, Selv-publiceret: CreateSpace.

Nelson, Maggie (2011): The Art of Cruelty: A Reckoning, New York: W.W. Norton \& Company, Inc. Nelson, Maggie (2017): The Red Parts: Autobiography of a Trial, London: Vintage.

O’Haver, Tommy (2007): An American Crime, First Look Films.

Poe, Edgar Allan (1993): Edgar Allan Poe: Complete Poems and Essays, London: Everyman.

Scarry, Elaine (1985): The Body in Pain: The Making and Unmaking of the World, New York: Oxford University Press.

Wall, Ingrid og Joachim Wall (2018): Bogen om Kim Wall: Når ordene slipper op, København: Gyldendal.

Wheat, Patte (1976): By Sanction of the Victim, Chatsworth: Major Books.

Wilson, Gregory M. (2007): Jack Ketchum's The Girl Next Door, Modern Girl Productions. 